Oikos 000: 000-000, 2011

doi: $10.1111 / j .1600-0706.2011 .19622 . x$

No claim to US government works. Oikos (C) 2011 Nordic Society Oikos

Subject Editor: Martin F. Quigley. Accepted: 21 June 2011

\title{
Forest dynamics following eastern hemlock mortality in the southern Appalachians
}

\author{
Chelcy R. Ford, Katherine J. Elliott, Barton D. Clinton, Brian D. Kloeppel and James M. Vose \\ C. R. Ford (crford@fs.fed.us), K. J. Elliott, B. D. Clinton and J. M. Vose, USDA Forest Service, Southern Research Station, Coweeta Hydrologic \\ Laboratory, Otto, NC 28763, USA. - B. D. Kloeppel, Dept of Geosciences and Natural Resources, Western Carolina Univ., Cullowhee, \\ NC 28723, USA.
}

\begin{abstract}
Understanding changes in community composition caused by invasive species is critical for predicting effects on ecosystem function, particularly when the invasive threatens a foundation species. Here we focus on dynamics of forest structure, composition and microclimate, and how these interact in southern Appalachian riparian forests following invasion by hemlock woolly adelgid, HWA, Adelges tsugae. We measured and quantified changes in microclimate; canopy mortality; canopy and shrub growth; understory species composition; and the cover and diversity in riparian forests dominated by eastern hemlock Tsuga canadensis over a period of seven years. Treatments manipulated hemlock mortality either through invasion (HWA infested stands) or girdling (GDL) hemlock trees.

Mortality was rapid, with $50 \%$ hemlock tree mortality occurring after six years of invasion, in contrast to more than $50 \%$ mortality in two years following girdling. Although $50 \%$ of hemlock trees were still alive five years after infestation, leaf area lost was similar to that of girdled trees. As such, overall responses over time (changes in light transmittance, growth, soil moisture) were identical to girdled stands with $100 \%$ mortality. Our results showed different growth responses of the canopy species, shrubs and ground layer, with the latter being substantially influenced by presence of the evergreen shrub, rhododendron Rhododendron maximum. Although ground layer richness in the infested and girdled stands increased by threefold, they did not approach levels recorded in hardwood forests without rhododendron. Increased growth of co-occurring canopy trees occurred in the first few years following hemlock decline, with similar responses in both treatments. In contrast, growth of rhododendron continued to increase over time. By the end of the study it had a 2.6-fold higher growth rate than expected, likely taking advantage of increased light available during leaf-off periods of the deciduous species. Increased growth and dominance of rhododendron may be a major determinant of future responses in southern Appalachian ecosystems; however, our results suggest hemlock will be replaced by a mix of Acer, Betula, Fagus and Quercus canopy genera where establishment is not limited by rhododendron.
\end{abstract}

Invasive species can fundamentally alter forest community dynamics, by altering both community composition and structure. Rates of invasive species' introductions (e.g. ship ballast water, plant industry, nursery stock, human housing, etc.) have dramatically increased in recent years (Enserink 1999, Padilla and Williams 2004, Hulme 2009), thereby altering species richness and biodiversity in many ecosystems (Daehler 2003, Crowl et al. 2008, Flory and Clay 2010). Changes in richness and diversity can occur simply by adding another species to the ecosystem, (i.e. the 'invasive'), by loss or displacement of native species due to competition, or in the case of invasive insects and disease, by direct extirpation (or near extirpation) of native species. For example, American chestnut Castanea dentata was effectively eliminated from eastern US forests by the chestnut blight fungus Cryphonectria parasitica which was introduced from Asia (Elliott and Swank 2008).

Understanding changes in community composition caused by invasive species is important because species, especially those that serve as the foundation species of a system (Ellison et al. 2005), can affect ecosystem function; for example, transpiration (Daley et al. 2007, Ford and Vose 2007); carbon cycling (Nuckolls et al. 2009, Cobb 2010); nutrient cycling (Stadler et al. 2005, 2006, Lovett et al. 2010); and plant and animal habitats (Gordon 1998). As the rate of species invasions increases, it will become even more important to predict their impacts on community structure, composition, and function as a guide to prioritizing control and eradication strategies (Ellison et al. 2005), and to identify and prioritize post-infestation restoration and management actions. To predict the effects of exotic pests and pathogens on community structure, composition, and function, Lovett et al. (2006) outlined six key features of the host and the pest or pathogen. Among the pest or pathogen's key features was 'virulence', related to how quickly decline and mortality progressed; and among the host's key features was 'phytosociology', related to how the overall forest is structured, and the importance and uniqueness of the host species within it. 
Changes in community structure can be as important as species compositional changes, as changes in structure can alter controls on ecosystem processes. For example, shrub encroachment in prairie alters ecosystem $\mathrm{C}$ inputs through a stimulation in leaf area index when shrubs replace grasses (Knapp et al. 2008), which also alters litter inputs and/or partitioning of light, nutrients and water (Norris et al. 2001, Lett and Knapp 2003). Controls on decomposition also differ between a grass- and a non-grass structured arid system (Austin and Vivanco 2006); and controls on nitrogen cycling differ between forests with shrub layers dominated by ericaceous species compared to those without an ericaceous shrub layer (Wurzburger and Hendrick 2007, 2009). Structural changes may also result in changes in microclimate. Loss of forest canopy due to tree death can result in a redistribution of available resources such as light and soil moisture. However, in areas occupied by dense stands of evergreen shrubs, these responses can be substantially muted. For example, light levels beneath evergreen shrubs, e.g. rhododendron Rhododendron maximum, can be as low as 5\% of full sun (Clinton 2003), well below the light compensation point for most woody species. Once established, thick shrub layers can limit recruitment by altering microclimate (Baker and van Lear 1998); thus, when structure alters microclimate, changes in composition can occur.

Forest ecosystems dominated by eastern hemlock Tsuga canadensis in the eastern US are undergoing fundamental changes in function and composition from infestations of hemlock woolly adelgid, HWA, Adelges tsugae. HWA is an invasive exotic insect native to Japan, first documented in eastern hemlock forests in the 1950s, that is attacking eastern hemlock trees of all ages and sizes (Elliott and Vose 2011), throughout much of the tree's range (Orwig et al. 2002). HWA infestation, hemlock mortality, and changes in ecosystem processes appear to occur more rapidly in the southern Appalachians compared to the forests in New England (Nuckolls et al. 2009), due in part to higher winter air temperatures that can sustain high HWA population numbers (Skinner et al. 2003, Trotter and Shields 2009). The northern-most extent of the effects of HWA has been reported to be constrained by air temperatures of $-30^{\circ} \mathrm{C}$ or lower sustained for at least $24 \mathrm{~h}$ (Parker et al. 1998). In contrast, in the southern Appalachians the adverse effects of HWA on hemlock populations are likely not constrained by temperature because these lethal minimum temperatures rarely, if ever, occur. For example, in a 75-year climate record in the Coweeta basin in the southern Appalachians, the absolute minimum air temperature recorded was $-27^{\circ} \mathrm{C}$ in Jan 1985 , and average minimum winter air temperature is $4^{\circ} \mathrm{C}$ (Laseter et al. in press).

Community dynamics following HWA infestation are poorly understood, especially for the southern Appalachians (Lovett et al. 2006), but will likely vary among land use histories and geographic regions, as HWA 'virulence' and host 'phytosociology' differ between hemlock forests in the northeast and in southern Appalachians. In their northern range, eastern hemlock occurs as largely monospecific and dense stands, and in areas historically protected from fire, agricultural and other human land uses (Foster and Zebryk 1993). In New England, black birch Betula lenta, a fast-growing, relatively shade-intolerant, early-successional tree species, dominates the forest community immediately following hemlock mortality (Orwig and Foster 1998, Cobb 2010). In the southern Appalachians, hemlock is a co-occurring canopy species found primarily along riparian corridors (Narayanaraj et al. 2009) where rhododendron is often abundant. Rhododendron is an important species in these forests as it is highly shade tolerant, forms a dense shrub layer that strongly attenuates light incident on the forest floor (Clinton 2003), has little to no herbaceous or seedling (henceforth understory) cover below its canopy (Clinton et al. 1994, Beckage et al. 2000), negatively affects tree seedling densities where they can establish (Hille Ris Lambers and Clark 2003), and decreases nitrogen availability in the soil and litter layer to non-ericaceous species (Wurzburger and Hendrick 2007, 2009). Thus, in the southern extent of the infestation range, community dynamics following mortality will likely be controlled by forest structure (e.g. shrub layer vs. no shrub layer) and the resulting microclimate.

Due to the complex community structure and composition in southern Appalachian forests dominated by hemlock, post-mortality successional dynamics may well either be dominated by rhododendron or advance regeneration (tree saplings $>0.5 \mathrm{~m}$ height) of co-occurring hardwood species, as many have speculated (Ford and Vose 2007, Kincaid and Parker 2008, Roberts et al. 2009). Our objectives are to characterize 1) changes in microclimate, 2) changes in tree species growth, composition and structure, and 3) ground layer cover and diversity in southern Appalachian riparian forests undergoing simulated and actual infestation by hemlock woolly adelgid. A simulated infestation, accomplished by girdling, provided an opportunity to contrast microclimate and community responses from a rapid, or highly 'virulent', disturbance (i.e. $100 \%$ hemlock mortality in 1-2 years) with a more gradual disturbance (i.e. 100\% hemlock mortality in 7-10 years) typical of HWA infestations in well studied geographic regions of the US. We hypothesized that 1) hemlock growth would decline over time, 2) shrub and canopy hardwood tree growth would increase over time, with smaller, but more protracted responses in the infested stands and 3) species diversity and richness in the ground layer would not change significantly over time in either girdled or infested stands due to the high density of rhododendron shrubs.

\section{Methods}

\section{Site description and experimental design}

The study site is located at the Coweeta Hydrologic Laboratory in the Nantahala Mountain range of western North Carolina, USA. Climate is classified as marine humid temperate with cool summers and mild winters (Swift et al. 1988). Average annual temperature is $12.6^{\circ} \mathrm{C}$, and ranges from an average of $3.3^{\circ} \mathrm{C}$ to $21.6^{\circ} \mathrm{C}$ in January and July, respectively. Average annual rainfall is $1794 \mathrm{~mm}$, and has become more variable in the last 20 years (Laseter et al. in press). Study plots were established in low elevation (730-1040 m) cove hardwood forests (Elliott et al. 1999). Plots were located in riparian zones in Inceptisols of the Cullasaja soil series. 
The experimental design had two main treatments, plots with girdled hemlock trees (hereafter, GDL plots) and plots with HWA infested hemlock trees (hereafter, HWA plots), each treatment with four replicate $20 \times 20 \mathrm{~m}$ plots. Hemlock comprised more than half of the total basal area in these treatment plots (Table 1). All hemlock trees in the GDL experimental plots (and within $5 \mathrm{~m}$ of the plot boundaries) were girdled by handsaw or chainsaw at breast height $(1.37 \mathrm{~m})$ in July 2004. Girdling depth was intended to sever the cambium, phloem and sapwood. We re-girdled trees during annual surveys in 2005 and 2006 if they still appeared alive. We also located four replicate $20 \times 20 \mathrm{~m}$ plots in neighboring hardwood-dominated riparian areas intended to serve as a reference or future forest condition (hereafter, REF plots). The REF plots were similar in aspect, slope, and elevation, and had similar hardwood composition as the experimental plots (including evergreen shrubs), but received no treatment, and contained less than 3\% hemlock basal area (Table 1).

HWA was first noticed on a few trees along the main roads in the Coweeta basin in the fall of 2003 and in Macon County, NC as early as 2002 (USDA Forest Service 2002). An extensive survey of permanent vegetation plots in the Coweeta basin found little or no infestation in the rest of the basin in 2003, but found significant infestation throughout the basin by 2005 (Elliott and Vose 2011). We first observed infestation in the HWA and GDL plots in December 2004; however, infestation levels were low and the hemlock crowns were full and healthy.
By 2005, hemlock trees were heavily infested with HWA and reduced crown vigor was obvious. Because our first observations of HWA infestation were in the fall of 2004 and not in the spring, infestation of the study trees was likely due to dispersal of the second generation of crawlers from nearby areas in early summer. This second generation settles on new growth, but instead of feeding on hemlock, it enters aestivation until October when they begin to feed (McClure 1989).

\section{Characterizing changes in incident light}

Photosynthetically active photon flux density incident on $5 \mathrm{~m}$ and $1 \mathrm{~m}$ above ground height $\left(Q_{i}\right.$, $\mu$ moles $\left.\mathrm{m}^{-2} \mathrm{~s}^{-1}\right)$ was estimated from GaAsP photodiodes calibrated against a commercial quantum sensor. Photodiodes were arrayed in an alternating grid pattern throughout the plot: $\mathrm{Q}_{\mathrm{i}}$ was measured at $5 \mathrm{~m}$ height $(\mathrm{n}=10)$, and at $1 \mathrm{~m}$ height $(\mathrm{n}=10)$. The former height is generally above the height of rhododendron shrubs while the latter height is below them. Sensors were queried every $60 \mathrm{~s}$ and $15 \mathrm{~min}$ averages were logged. Due to the sampling intensity of spatial and temporal $\mathrm{Q}_{\mathrm{i}}$ data, only two replicate plots in each treatment had photodiode arrays. Arrays were installed in late fall 2005 and removed in early fall 2009. To characterize the change in incident light on the two heights over time, we calculated light transmittance $\left(\mathrm{Q}_{\mathrm{i}} / \mathrm{Q}_{\mathrm{o}}\right)$, where $\mathrm{Q}_{\mathrm{o}}\left(\mu\right.$ moles $\left.\mathrm{m}^{-2} \mathrm{~s}^{-1}\right)$ was measured at an open-field climate station located approximately $2 \mathrm{~km}$ from the sites.

Table 1. Canopy and shrub species mean (SD) density and basal area for the three treatments; girdled (GDL), HWA-infested (HWA), and neighboring hardwoods (REF) in 2004. Only stems $>2.54 \mathrm{~cm} \mathrm{DBH}$ are presented. Basal area values in bold denote $\geq 5 \%$ basal area contributed by the species (sum of all bold values within a column is at least $79 \%$ of total basal area).

\begin{tabular}{|c|c|c|c|c|c|c|c|c|c|c|c|c|}
\hline \multirow[b]{3}{*}{ Acer pensylvanicum } & \multicolumn{6}{|c|}{ Density (stems ha-1) } & \multicolumn{6}{|c|}{ Basal area $\left(\mathrm{m}^{2} \mathrm{ha}^{-1}\right)$} \\
\hline & \multicolumn{2}{|c|}{ GDL } & \multicolumn{2}{|c|}{ HWA } & \multicolumn{2}{|c|}{ REF } & \multicolumn{2}{|c|}{ GDL } & \multicolumn{2}{|c|}{ HWA } & \multicolumn{2}{|c|}{ REF } \\
\hline & 0 & (0) & 6 & (13) & 13 & (25) & 0.00 & $(0.00)$ & 0.00 & $(0.00)$ & 0.03 & $(0.06)$ \\
\hline A. rubrum & 63 & $(52)$ & 38 & (43) & 156 & $(66)$ & 1.44 & $(1.84)$ & 0.60 & $(0.71)$ & 2.05 & $(2.68)$ \\
\hline Amelanchier arborea & 6 & (13) & 0 & (0) & 0 & (0) & 0.06 & $(0.12)$ & 0.00 & $(0.00)$ & 0.00 & $(0.00)$ \\
\hline Betula lenta & 100 & (84) & 175 & (159) & 81 & (69) & 3.24 & $(\mathbf{1 . 3 0})$ & 3.69 & $(3.92)$ & 2.21 & $(2.38)$ \\
\hline Carpinus caroliniana & 0 & $(0)$ & 0 & (0) & 63 & (63) & 0.00 & $(0.00)$ & 0.00 & $(0.00)$ & 0.25 & $(0.34)$ \\
\hline Carya spp. & 13 & (14) & 6 & (13) & 56 & $(66)$ & 0.48 & $(0.88)$ & 1.56 & $(3.12)$ & 0.96 & $(1.11)$ \\
\hline Cornus florida & 0 & $(0)$ & 6 & (13) & 219 & $(185)$ & 0.00 & $(0.00)$ & 0.02 & $(0.03)$ & 0.74 & $(0.70)$ \\
\hline Fagus grandifolia & 0 & $(0)$ & 6 & (13) & 31 & $(24)$ & 0.00 & $(0.00)$ & 0.04 & $(0.08)$ & 0.60 & $(0.67)$ \\
\hline Fraxinus americana & 6 & (13) & 0 & (0) & 19 & (38) & 0.81 & $(1.63)$ & 0.00 & $(0.00)$ & 0.00 & $(0.00)$ \\
\hline Hamamelis virginiana & 25 & (29) & 0 & (0) & 0 & $(0)$ & 0.06 & $(0.08)$ & 0.00 & $(0.00)$ & 0.00 & $(0.00)$ \\
\hline Kalmia latifolia & 31 & $(63)$ & 31 & (63) & 0 & $(0)$ & 0.17 & $(0.33)$ & 0.08 & $(0.15)$ & 0.02 & $(0.05)$ \\
\hline Liriodendron tulipifera & 50 & $(100)$ & 69 & (55) & 100 & (89) & 2.16 & $(4.32)$ & 2.32 & $(1.19)$ & 7.85 & $(9.02)$ \\
\hline Magnolia fraseri & 0 & $(0)$ & 13 & (25) & 6 & (13) & 0.00 & $(0.00)$ & 0.40 & $(0.80)$ & 0.00 & $(0.00)$ \\
\hline Nyssa sylvatica & 38 & (43) & 6 & (13) & 44 & $(52)$ & 2.55 & $(3.24)$ & 0.83 & $(1.67)$ & 1.38 & $(1.75)$ \\
\hline Oxydendrum arboreum & 44 & $(31)$ & 119 & $(160)$ & 175 & $(172)$ & 1.20 & $(0.92)$ & 1.94 & $(2.23)$ & 3.05 & $(\mathbf{1 . 8 6})$ \\
\hline Pinus rigida & 0 & $(0)$ & 25 & (35) & 0 & $(0)$ & 0.00 & $(0.00)$ & 1.51 & $(1.81)$ & 0.00 & $(0.00)$ \\
\hline P. strobus & 0 & $(0)$ & 0 & (0) & 25 & (35) & 0.00 & $(0.00)$ & 0.00 & $(0.00)$ & 0.05 & $(0.09)$ \\
\hline Quercus alba & 31 & $(47)$ & 6 & (13) & 144 & $(97)$ & 3.04 & $(3.42)$ & 0.65 & $(1.31)$ & 29.20 & (15.15) \\
\hline Q. coccinea & 13 & $(25)$ & 0 & $(0)$ & 0 & $(0)$ & 1.13 & $(2.26)$ & 0.00 & $(0.00)$ & 0.00 & $(0.00)$ \\
\hline Q. montana & 13 & (14) & 0 & (0) & 0 & $(0)$ & 1.82 & $(2.72)$ & 0.00 & $(0.00)$ & 0.00 & $(0.00)$ \\
\hline Q. rubra & 6 & $(13)$ & 6 & (13) & 6 & $(13)$ & 0.30 & $(0.60)$ & 2.55 & $(5.10)$ & 2.22 & $(4.43)$ \\
\hline Rhododendron maximum & 1944 & $(300)$ & 1806 & $(277)$ & 1563 & $(1382)$ & 5.13 & (1.83) & 4.43 & $(0.53)$ & 3.16 & $(2.70)$ \\
\hline Robinia pseudoacacia & 13 & $(25)$ & 0 & $(0)$ & 13 & $(25)$ & 0.00 & $(0.00)$ & 0.02 & $(0.03)$ & 0.42 & $(0.83)$ \\
\hline Sassafras albidum & 19 & $(38)$ & 13 & (14) & 0 & $(0)$ & 0.33 & $(0.66)$ & 0.20 & $(0.24)$ & 0.00 & $(0.00)$ \\
\hline Tsuga canadensis & 600 & $(247)$ & 713 & $(365)$ & 38 & $(48)$ & 22.76 & (11.57) & 31.23 & $(9.66)$ & 0.15 & $(0.21)$ \\
\hline Vitis spp. & 0 & $(0)$ & 19 & (24) & 0 & (0) & 0.00 & $(0.00)$ & 0.01 & $(0.03)$ & 0.00 & $(0.00)$ \\
\hline Total & 3013 & (485) & 3063 & (633) & 2750 & $(1512)$ & 46.67 & $(16.44)$ & 52.10 & $(12.11)$ & 54.35 & $(16.74)$ \\
\hline
\end{tabular}




\section{Soil moisture}

To quantify changes in soil moisture, we installed three time domain reflectometry (TDR) probes that were $30 \mathrm{~cm}$ in length in each plot in fall 2005. Probes were installed vertically in the mineral soil and sensed the average percent volumetric soil moisture $(\mathrm{v} / \mathrm{v} \%)$ in the $0-30 \mathrm{~cm}$ depth. Sensors were queried every $15 \mathrm{~min}$ and $60 \mathrm{~min}$ averages were logged. Concurrent measurements were conducted on all treatment plots until early spring 2008. Due to the high organic matter in these soils, we calibrated TDR probes using measured volumetric soil moisture content in the lab for each soil type.

\section{Mortality, basal area increment and recruitment surveys}

In 2004, we tagged all stems with diameters greater than $2.54 \mathrm{~cm}$ at $1.37 \mathrm{~m}$ height. We chose a minimum stem diameter of $2.54 \mathrm{~cm}$ at $1.37 \mathrm{~m}$ for all woody vegetation to focus on established saplings and larger trees, and to quantify the growth and/or mortality of these stems. Herbaceous and woody seedling population dynamics were captured in the ground layer vegetation surveys. Individuals were assessed for mortality status, and considered alive if any green foliage or live buds were visually present in the canopy, and dead otherwise. All stems with diameters greater than $15 \mathrm{~cm}$ were fitted with dendrometer bands (Cattelino et al. 1986) at $1.37 \mathrm{~m}$ in 2004 . All stems, including those smaller than $15 \mathrm{~cm}$, and dendrometer bands were measured annually with a diameter tape to the nearest $0.1 \mathrm{~cm}$ or with digital calipers to the nearest $0.01 \mathrm{~mm}$. During the annual surveys, if a stem that measured $2.54 \mathrm{~cm}$ in diameter at $1.37 \mathrm{~m}$ above ground height was encountered that had not been tagged and measured in the previous year, it was measured and considered recruitment from the understory layer. Since our first diameter measurements were made at the end of 2004, the first year that we could calculate stem growth increment was 2005 . We determined annual basal area increment (BAI) from the difference of successive annual growth measured at the end of each year. We calculated mean BAI of hemlock trees, co-occurring hardwood trees and evergreen shrubs in the treatment plots. BAI of each group was expected to be highly dynamic among years, as inter-annual variability in tree growth is highly reflective of climatic conditions (Fritts 1976). To isolate the differences in hemlock, co-occurring hardwoods, and shrub BAI due to treatments rather than climate, we calculated a ratio of hemlock BAI to the BAI of hardwood stems in the neighboring hardwood reference plots; a ratio of co-occurring hardwood $\mathrm{BAI}$ in the treatment stands to the BAI of hardwood stems in the neighboring hardwood reference plots; and a ratio of shrub BAI in the treatment stands to the shrub BAI in the neighboring hardwood reference plots (a similar approach to Nuckolls et al. 2009). The numerator in all ratios was the mean BAI of hemlock, cooccurring hardwoods or evergreen shrubs. The denominator in all ratios was the mean BAI growth of the hardwoods (in the two former cases) or the shrubs (in the latter case) in the REF plots.

\section{Ground layer vegetation surveys}

We sampled the ground layer vegetation seasonally; a design allowing us to capture the phenology of short-lived woodland herbs in addition to herbaceous perennials and longer-live annuals (Whigham 2004). Surveys took place in summer (early August) of 2004, summer (mid July) and late summer (September) of 2006, and spring (May), summer, and late summer of 2007, 2008 and 2010. We used the lineintercept method (Clarke 1986) to record all plants (woody stems $<0.5 \mathrm{~m}$ height and all herbaceous plants) by species. One $20 \mathrm{~m}$ line-transect was placed within each $20 \times 20 \mathrm{~m}$ plot. We recorded the length intercepted by each species to the nearest $1.0 \mathrm{~cm}$. All species nomenclature follows Gleason and Cronquist (1991).

We calculated percent cover $\left(\mathrm{m}^{2} \mathrm{~m}^{-2}\right)$ of each species by summing its total distance along the line-transect and dividing by the total transect length. Presence of each tree seedling by species was also recorded along each transect. We calculated species richness ( $S$, number of species) and Shannon's index of diversity ( $\mathrm{H}^{\prime}$, Magurran 2004) based on percent cover for each plot. As with BAI, we also calculated the ratio of the mean percent cover, $S, \mathrm{H}^{\prime}$, and number of tree seedlings in the GDL and HWA plots to the mean percent cover, $S$, and $\mathrm{H}^{\prime}$, and number of tree seedlings in the REF plots to account for inter-annual variability in climate.

\section{Statistical models}

To characterize temporal patterns of hemlock mortality, we fit a logistic model to the observed cumulative frequency mortality data over time $(\mathrm{t})$. The model took the form

$$
f(t)=y_{0}+\frac{100}{1+e^{-\left(\frac{t-t_{0}}{b}\right)}},
$$

where $y_{0}$ is the intercept or the baseline level of mortality, $\mathrm{t}_{0}$ is the point in time where $50 \%$ mortality is predicted, and the numerator was constrained to 100 to reflect the upper limit of the response (i.e. asymptote). If terms could be omitted for parsimony (e.g. $y_{0}$ ), we omitted them. We fit this simple statistical model to the data to aid in inferring when $100 \%$ mortality would be expected in the case it was not observed.

We tested for treatment and time effects in the BAI ratios, understory layer cover, species richness $(S)$, diversity $\left(\mathrm{H}^{\prime}\right)$, $\mathrm{Q}_{\mathrm{i}} / \mathrm{Q}_{\mathrm{o}}$ and soil moisture using a mixed linear model with repeated measures (PROC MIXED, SAS). We used the covariance option in the repeated statement that produced the smallest value for the Akaike's information criterion (AIC) and Schwarz' Bayesian criterion (SBC) (Little et al. 1996). We evaluated the main effects of time, treatment, and time by treatment interactions. If overall F-tests were significant $(\mathrm{p} \leq 0.05)$ then least squares means (LS-means, Tukey-Kramer adjusted t-statistic) tests were used to evaluate significance among treatments, and times. We transformed variables to meet normality assumptions if necessary. Because our hypotheses were stated to expect increases in the BAI ratio of shrubs and co-occurring hardwoods, and decreases 
in the BAI ratio of eastern hemlock, these post hoc tests were one-tailed; all others were two-tailed.

To explore whether various responses were correlated over time, we also calculated simple Pearson's correlation coefficients among hemlock mortality, BAI ratios and changes in $\mathrm{Q}_{\mathrm{i}} / \mathrm{Q}_{\mathrm{o}}$ among years.

\section{Results}

\section{Light and soil moisture}

Maximum daily light transmittance varied seasonally. Light incident on 1 and $5 \mathrm{~m}$ above the ground during leaf-off periods of the deciduous species (winter and spring) was between three and four fold greater than during leaf-on periods. Over the four years of measurement, incident light transmittance increased significantly. Temporal changes were most pronounced during leaf-off periods (winter and spring), although significant (but less pronounced), increases were also observed during summer and fall (Fig. 1). We thus focus on the differences between treatments and measurement heights during the winter and spring seasons.

Understory layer transmittance in winter was 1.5 times higher in the HWA treatment plots compared to GDL (treatment effect, $F_{1,3}=16.00, p=0.03$ ), likely due to the greater rhododendron stem density and basal area in the latter compared to the former (Table 1). Winter maximum daily light

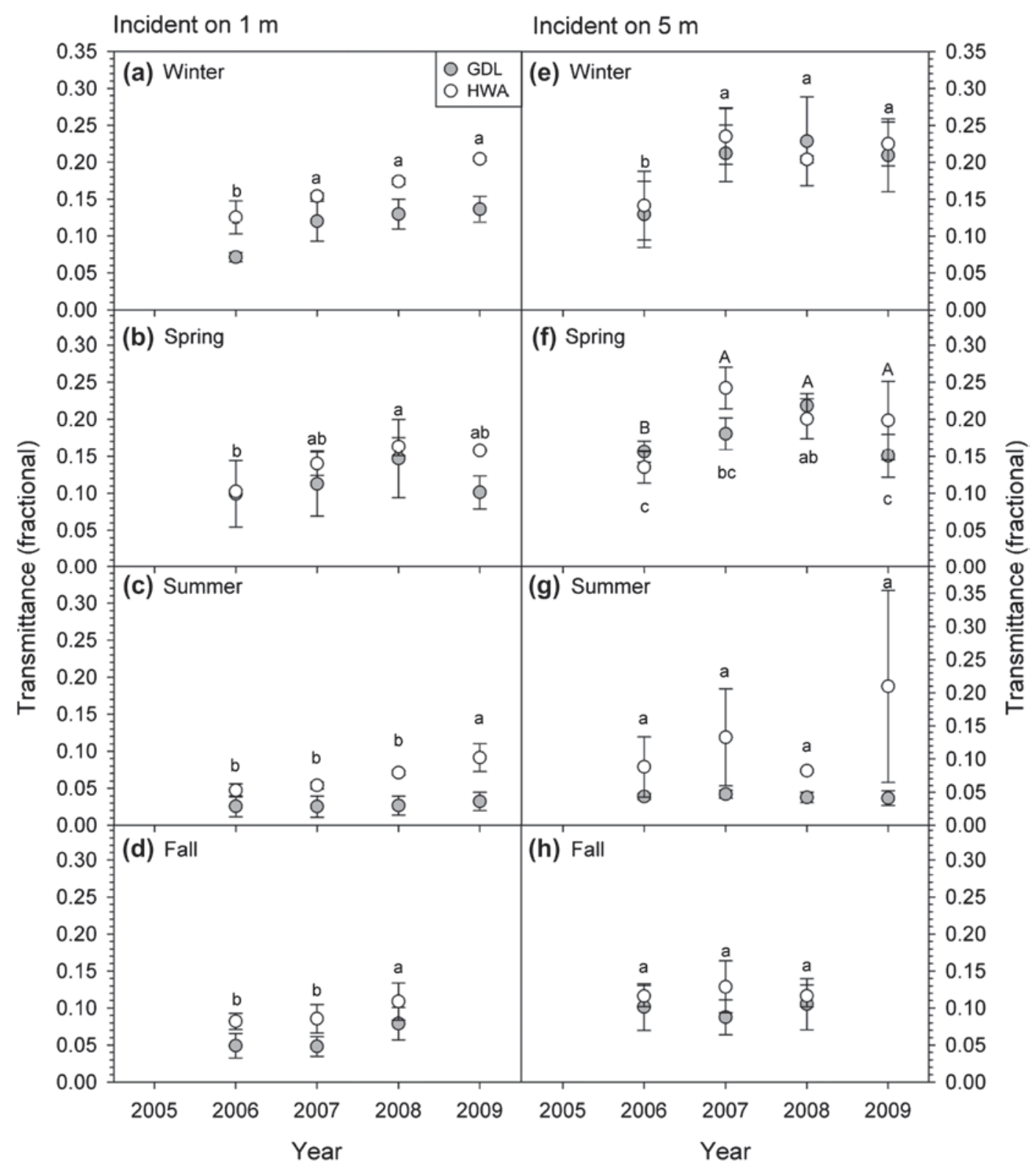

Figure 1. Seasonal averages of maximum daily $\mathrm{Q}_{\mathrm{i}} / \mathrm{Q}_{0}$ in treatment plots $(\mathrm{n}=2)(\mathrm{GDL}$, grey; HWA, white) at two heights above ground level (1 or $5 \mathrm{~m}$ ). Bars denote SE. Different letters denote statistically significant differences among sample years. In panel (f) the treatment by time interaction was significant; uppercase letters correspond to HWA treatment differences and lowercase correspond to GDL. Girdling occurred in July 2004. HWA infestation was observed in December 2004. 
transmittance into $1 \mathrm{~m}$ increased over time by a factor of ca 2 (year effect, $\mathrm{F}_{3,5}=21.30, \mathrm{p}=0.003$ ). Both treatments displayed similar winter increases at $1 \mathrm{~m}$ over time (no treatment by time interaction, $\mathrm{F}_{3,5}=1.30, \mathrm{p}=0.37$ ). In spring, maximum daily transmittance onto $1 \mathrm{~m}$ above ground height was similar in both treatments (no treatment effect, $\left.\mathrm{F}_{1,3}=0.97, \mathrm{p}=0.39\right)$, and the increase in transmittance over time (year effect $\mathrm{F}_{3,5}=9.20, \mathrm{p}=0.02$ ) again displayed the same pattern in both treatments (no treatment by time interaction, $\mathrm{F}_{3,5}=2.15, \mathrm{p}=0.21$ ). Spring maximum daily transmittance increased steadily from $10 \%$ in 2006 to $15 \%$ only until 2008; however, transmittance in 2009 was similar to that measured in previous years. This decline in spring transmittance $1 \mathrm{~m}$ above ground height during the last year of the study occurred simultaneously with dramatic increases in shrub growth.

Maximum daily light transmittance $5 \mathrm{~m}$ above ground height was 1.6 times higher (SE 0.06) than that incident on $1 \mathrm{~m}$ above ground height across all years and treatments (Fig. 1), due in part to the presence of the shrubs attenuating light between 1 and $5 \mathrm{~m}$. Transmittance incident on $5 \mathrm{~m}$ in winter was similar in HWA and GDL treatments (no treatment effect, $F_{1,3}=0.05, p=0.84$ ). Winter light transmittance incident $5 \mathrm{~m}$ above ground height increased over time by a factor of 1.7 (year effect, $F_{3,5}=9.85, p=0.02$ ), and displayed the same pattern in both treatments (no treatment by time interaction, $\mathrm{F}_{3,5}=0.64, \mathrm{p}=0.62$ ). In spring, transmittance incident on $5 \mathrm{~m}$ changed differently over time in the two treatments (no treatment effect, $\mathrm{F}_{1,3}=0.46, \mathrm{p}=0.55$; year effect $\mathrm{F}_{3,5}=43.64, \mathrm{p}<0.001$; treatment by time interaction, $\left.\mathrm{F}_{3,5}=20.51, \mathrm{p}=0.003\right)$. In HWA infested stands, transmittance increased from $13 \%$ in 2006 to $24 \%$ in 2007 , a factor of 1.8 , and remained similar thereafter. In the GDL stands, transmittance increased steadily from 16\% in 2006 to $22 \%$ only until 2008 , a factor of 1.4 ; transmittance in 2009 was similar to that measured in 2006, however.

Although the GDL plots tended to have the highest soil moisture among the treatments, this was not significant (no treatment effect $\mathrm{F}_{2,4}=2.69, \mathrm{p}=0.18$ ) (Fig. 2). Seasonal variation differed among treatments (treatment by time interaction $\left.\mathrm{F}_{18,26}=4.61, \mathrm{p}<0.001\right)$. In general, seasonal maxima occurred in winter and minima occurred in summer. Mean seasonal soil moisture was also relatively high during the study period ranging 16.6-33\% in HWA and 27.7-39.8\% in GDL treatment plots.

\section{Mortality and growth responses of canopy and shrub species}

Mortality of eastern hemlock increased significantly over time; however, mortality of infested trees did not progress as quickly or completely as girdled trees (Fig. 3) $(b=0.67$ vs 0.48 , respectively). Fifty percent hemlock tree mortality occurred by 2010 in the HWA infested plots. In contrast, half the girdled hemlock population experienced mortality by 2005 , in just two years. By using a fitted mortality model to the frequency data, we expect that $100 \%$ mortality will occur in the infested plots by 2012 .

As expected, hemlock BAI declined over time, and hemlock BAI in the GDL plots declined more rapidly compared to those in the HWA plots (treatment by time interaction $\mathrm{F}_{4,23}=5.61, \mathrm{p}<0.01$; Fig. 4a). Co-occurring hardwoods in both the GDL and HWA treatment plots showed increased growth in response to the treatments two years after girdling and infestation (no treatment effect, but a significant year effect, $\mathrm{F}_{4,24}=5.51, \mathrm{p}<0.01$; Fig. $4 \mathrm{~b}$ ), and increases again in the last two years of the study. The tree species that were primarily responsible for the increased growth due to infestation and girdling over the study period were Acer rubrum (comprised $7.2 \% \pm 8.0 \% \mathrm{SD}$ of the response), Betula lenta $(25.5 \% \pm 20.6 \%$ SD), and Liriodendron tulipifera $(16.7 \% \pm 21.8 \% \mathrm{SD})$.

Evergreen shrubs in both the GDL and HWA treatment plots increased growth in response to the treatments beginning four years after girdling and infestation (no treatment effect, but a significant year effect, $\mathrm{F}_{4,24}=27.91, \mathrm{p}<0.001$;

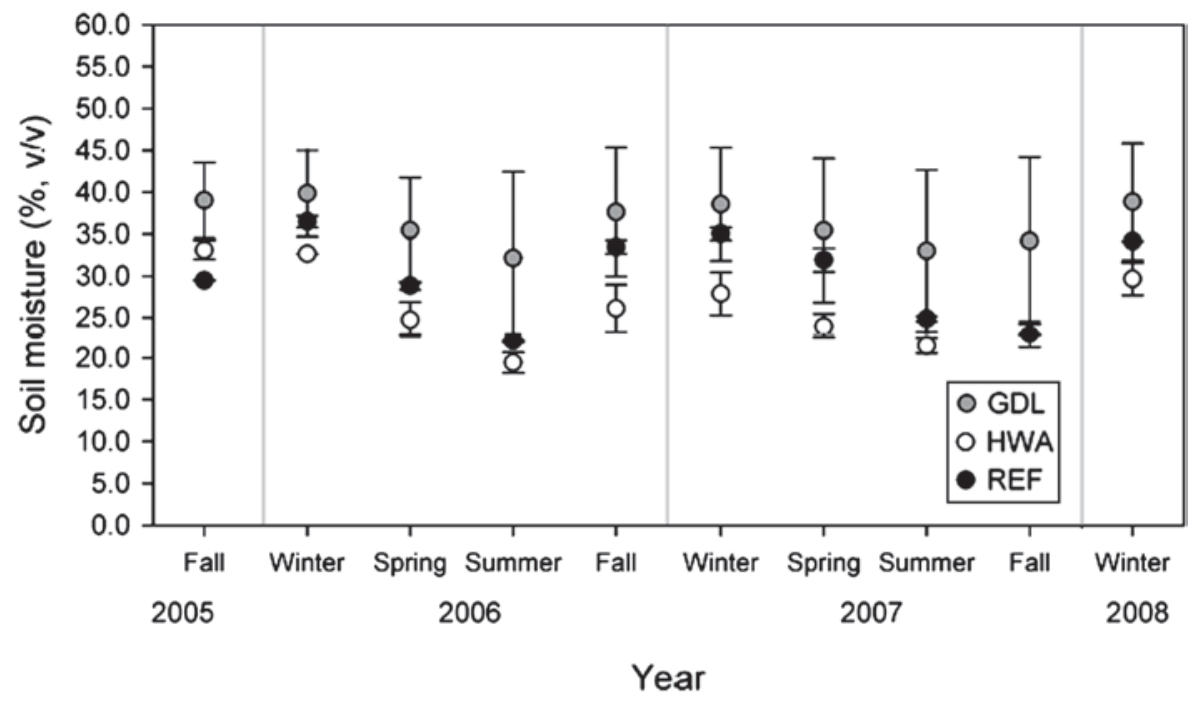

Figure 2. Seasonal averages of mean volumetric soil moisture content $(n=2)$ in girdled (GDL), HWA infested plots (HWA), and hardwood reference stands (REF). Girdling occurred in July 2004. HWA infestation was observed in December 2004. Bars denote SE. Significant seasonal differences occurred for all treatments; although within a season, treatments were never significantly different (see text for details). 


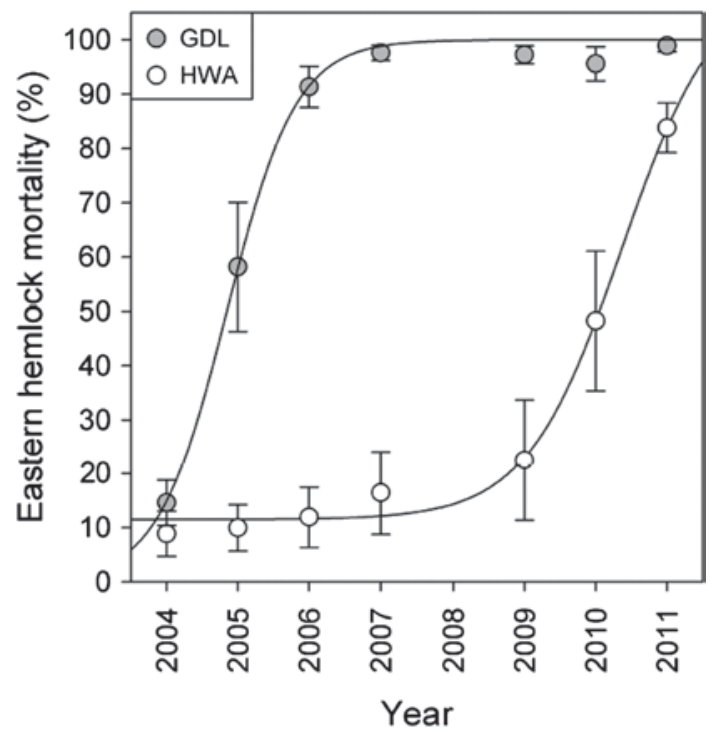

Figure 3. Cumulative frequency of eastern hemlock mortality in the girdled (GDL) and infested (HWA) treatment plots over time. Symbols are the mean (SE) among plots. Lines are the fitted mortality model for HWA, $\mathrm{f}(\mathrm{t})=\mathrm{y} 0+100 /\left(1+\exp \left(-\left(\mathrm{t}-\mathrm{t}_{0}\right) / \mathrm{b}\right)\right)$; $\mathrm{y} 0=11.5, \mathrm{~b}=0.67, \mathrm{t}_{0}=2010, \mathrm{R}^{2}=0.99, \mathrm{p}<0.001$. Mortality model for GDL, $\mathrm{f}(\mathrm{t})=100 /\left(1+\exp \left(-\left(\mathrm{t}-\mathrm{t}_{0}\right) / \mathrm{b}\right)\right) ; \mathrm{b}=0.48$, $\mathrm{t}_{0}=2005, \mathrm{R}^{2}=0.99, \mathrm{p}<0.001$. Girdling occurred in July 2004. HWA infestation was observed in December 2004.

Fig. 4c). In the fifth year following girdling and infestation, BAI growth by the shrubs was more than two-fold higher than the BAI growth of shrubs in nearby hardwood plots with $<3 \%$ hemlock basal area.

The BAI response of evergreen shrubs and co-occurring hardwoods were correlated $(\mathrm{R}=0.65, \mathrm{p}=0.04, \mathrm{n}=10)$, as was the BAI response of evergreen shrubs and cumulative hemlock mortality in HWA plots $(\mathrm{R}=0.89, \mathrm{p}=0.04$, $n=5$ ). BAI response of evergreen shrubs and cumulative hemlock mortality in GDL plots were not correlated due to the low variation in the latter variable during 2005-2009.

\section{Ground layer}

Cover, richness, diversity, and tree seedling density in the ground layer varied significantly between treatments and among years, contrary to our hypothesis. Cover, richness, diversity, and tree seedling density were significantly different among treatments (overall treatment effect, $\mathrm{F}_{2,40}=11.56$, $\mathrm{p}<0.001$ for cover; $\mathrm{F}_{2,40}=17.62, \mathrm{p}<0.001$ for richness; $\mathrm{F}_{2,40}=14.24, \mathrm{p}<0.001$ for diversity; and $\mathrm{F}_{2,40}=7.91$, $\mathrm{p}=0.0013$ for tree seedling density, Table 2). From 2004 to 2007, the REF treatment consistently had higher cover, richness, diversity, and tree seedling density than the GDL or HWA treatments. In 2008 and 2010, however, there were no longer significant differences among treatments (Table 2). In the summer of 2004 , only four species were present across all GDL plots (Table 3) with an average of 2.0 species per plot (Table 2 ). Ten species were present across all HWA plots with an average of 4.5 species per plot. The REF plots had more than twice the number of species than either the GDL or HWA plots (Table 3). In the following

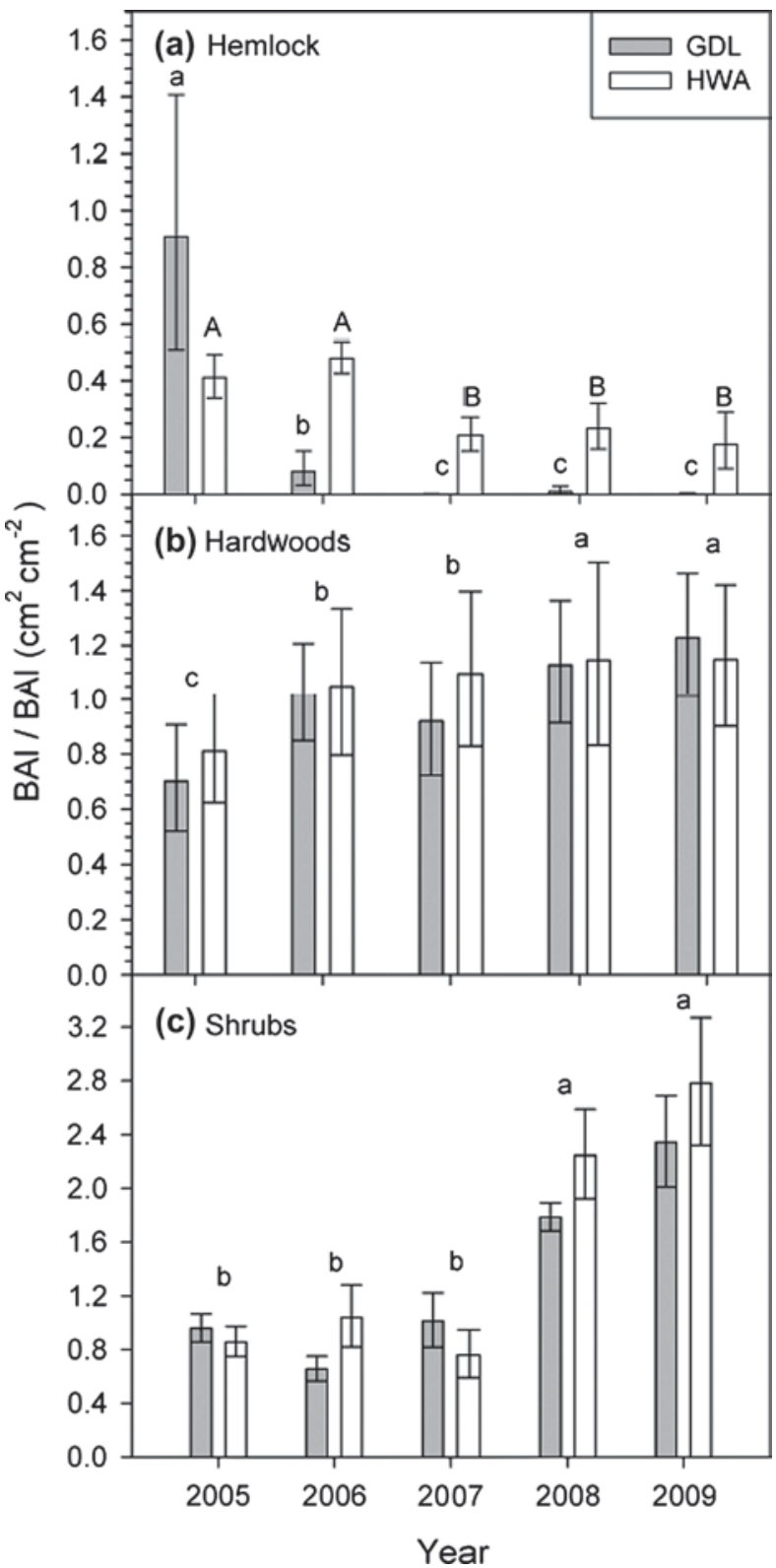

Figure 4. Mean annual basal area increment (BAI) of hemlock trees (a), co-occurring hardwood trees (b), and evergreen shrubs in girdled (GDL) and HWA treatments relative to the BAI of hardwood trees (a-b) or evergreen shrubs (c) in nearby stands with $<3 \%$ hemlock basal area. Bars denote standard error. Different letters denote statistically significant differences among years where no treatment effect was detected $(b-c)$. If a treatment by time interaction was detected (a), compare different UC and LC letters within a treatment ( $\alpha=0.05$, one-tailed). Girdling occurred in July 2004. HWA infestation was observed in December 2004.

years, the number of species present increased by threefold across the GDL and HWA plots. Tree seedlings, particularly red maple Acer rubrum, black birch, tulip poplar Liriodendron tulipifera, sourwood Oxydendrum arboreum, scarlet oak Quercus coccinea and northern red oak Quercus rubra, accounted for many of the new recruits (Table 3).

At the beginning of the experiment, the ratios of mean percent cover, richness and diversity in the GDL and 
Table 2. Ground layer vegetation mean (SE) cover $\left(\%, \mathrm{~m}^{2} \mathrm{~m}^{-2}\right)$, species richness ( $\mathrm{S}$, number of species per plot), diversity $\left(\mathrm{H}^{\prime}\right.$, Shannon's diversity index), and tree seedling density (seedlings $\mathrm{m}^{-2}$ ) over six years (2004-2010) for the three treatments; girdled (GDL), HWA-infested (HWA), and neighboring hardwoods (REF, $<3 \%$ hemlock basal area. Ground layer vegetation includes woody stems $<0.5 \mathrm{~m}$ height and all herbaceous plants. Values followed by different letters within rows are significantly different $(\alpha \leq 0.05)$.

\begin{tabular}{|c|c|c|c|c|c|c|c|c|c|c|c|c|c|}
\hline & & \multicolumn{3}{|c|}{ Cover } & \multicolumn{3}{|c|}{$S$} & \multicolumn{3}{|c|}{$\mathrm{H}^{\prime}$} & \multicolumn{3}{|c|}{ Tree seedlings } \\
\hline & & GDL & HWA & REF & GDL & HWA & REF & GDL & HWA & REF & GDL & HWA & REF \\
\hline 2004 & Aug & $\begin{array}{l}3.28 \mathrm{~b} \\
(1.34)\end{array}$ & $\begin{array}{l}4.26 \mathrm{~b} \\
(2.25)\end{array}$ & $\begin{array}{l}10.83 \mathrm{a} \\
(4.44)\end{array}$ & $\begin{array}{l}2.0 \mathrm{~b} \\
(0.6)\end{array}$ & $\begin{array}{l}4.5 \mathrm{~b} \\
(1.3)\end{array}$ & $\begin{array}{l}11.7 \mathrm{a} \\
(3.5)\end{array}$ & $\begin{array}{l}0.111 \mathrm{~b} \\
(0.027)\end{array}$ & $\begin{array}{l}0.160 \mathrm{~b} \\
(0.078)\end{array}$ & $\begin{array}{l}0.440 \mathrm{a} \\
(0.164)\end{array}$ & $0.0 \mathrm{~b}$ & $\begin{array}{l}0.5 \mathrm{~b} \\
(0.3)\end{array}$ & $\begin{array}{l}17.7 \mathrm{a} \\
(8.9)\end{array}$ \\
\hline \multirow[t]{2}{*}{2006} & Jul & $\begin{array}{l}5.28 \mathrm{~b} \\
(0.80)\end{array}$ & $\begin{array}{l}4.20 \mathrm{~b} \\
(1.48)\end{array}$ & $\begin{array}{l}13.29 \mathrm{a} \\
(6.19)\end{array}$ & $\begin{array}{l}4.2 \mathrm{~b} \\
(0.9)\end{array}$ & $\begin{array}{l}5.2 \mathrm{~b} \\
(1.9)\end{array}$ & $\begin{array}{l}13.0 \mathrm{a} \\
(4.0)\end{array}$ & $\begin{array}{l}0.193 b \\
(0.017)\end{array}$ & $\begin{array}{l}0.164 b \\
(0.059)\end{array}$ & $\begin{array}{l}0.507 \mathrm{a} \\
(0.208)\end{array}$ & $\begin{array}{l}8.2 \mathrm{ab} \\
(1.8)\end{array}$ & $\begin{array}{l}4.8 \mathrm{~b} \\
(3.1)\end{array}$ & $\begin{array}{l}15.7 \mathrm{a} \\
(7.9)\end{array}$ \\
\hline & Sep & $\begin{array}{l}4.42 \mathrm{~b} \\
(1.04)\end{array}$ & $\begin{array}{l}2.86 \mathrm{~b} \\
(1.07)\end{array}$ & $\begin{array}{l}11.04 \mathrm{a} \\
(3.86)\end{array}$ & $\begin{array}{l}4.2 \mathrm{~b} \\
(1.0)\end{array}$ & $\begin{array}{l}4.8 \mathrm{~b} \\
(1.2)\end{array}$ & $\begin{array}{l}13.0 \mathrm{a} \\
(3.0)\end{array}$ & $\begin{array}{l}0.170 \mathrm{~b} \\
(0.027)\end{array}$ & $\begin{array}{l}0.128 \mathrm{~b} \\
(0.047)\end{array}$ & $\begin{array}{l}0.433 \mathrm{a} \\
(0.147)\end{array}$ & & & \\
\hline \multirow[t]{3}{*}{2007} & May & $\begin{array}{l}3.63 \mathrm{~b} \\
(1.37)\end{array}$ & $\begin{array}{l}2.50 \mathrm{~b} \\
(1.14)\end{array}$ & $\begin{array}{l}8.00 \mathrm{a} \\
(3.44)\end{array}$ & $\begin{array}{l}4.2 \mathrm{~b} \\
(1.0)\end{array}$ & $\begin{array}{l}4.0 \mathrm{~b} \\
(1.7)\end{array}$ & $\begin{array}{l}10.0 \mathrm{a} \\
(2.5)\end{array}$ & $\begin{array}{l}0.136 \mathrm{~b} \\
(0.029)\end{array}$ & $\begin{array}{l}0.113 \mathrm{~b} \\
(0.049)\end{array}$ & $\begin{array}{l}0.324 \mathrm{a} \\
(0.122)\end{array}$ & & & \\
\hline & Jul & $\begin{array}{l}2.78 \mathrm{~b} \\
(0.59)\end{array}$ & $\begin{array}{l}2.89 \mathrm{~b} \\
(1.27)\end{array}$ & $\begin{array}{l}9.38 \mathrm{a} \\
(3.03)\end{array}$ & $\begin{array}{l}3.7 \mathrm{~b} \\
(0.8)\end{array}$ & $\begin{array}{l}3.5 \mathrm{~b} \\
(1.5)\end{array}$ & $\begin{array}{c}13.0 \mathrm{a} \\
(4.0)\end{array}$ & $\begin{array}{l}0.120 b \\
(0.015)\end{array}$ & $\begin{array}{l}0.126 \mathrm{~b} \\
(0.055)\end{array}$ & $\begin{array}{l}0.381 \mathrm{a} \\
(0.122)\end{array}$ & $\begin{array}{l}4.5 \mathrm{~b} \\
(0.9)\end{array}$ & $\begin{array}{l}2.2 \mathrm{~b} \\
(1.4)\end{array}$ & $\begin{array}{c}17.0 \mathrm{a} \\
(7.9)\end{array}$ \\
\hline & Sep & $\begin{array}{l}2.66 \mathrm{~b} \\
(0.76)\end{array}$ & $\begin{array}{l}2.64 \mathrm{~b} \\
(1.25)\end{array}$ & $\begin{array}{l}8.06 \mathrm{a} \\
(2.90)\end{array}$ & $\begin{array}{l}4.2 \mathrm{~b} \\
(1.3)\end{array}$ & $\begin{array}{l}3.7 \mathrm{~b} \\
(1.3)\end{array}$ & $\begin{array}{l}11.3 \mathrm{a} \\
(4.2)\end{array}$ & $\begin{array}{l}0.110 \mathrm{~b} \\
(0.021)\end{array}$ & $\begin{array}{l}0.114 \mathrm{~b} \\
(0.048)\end{array}$ & $\begin{array}{l}0.338 \mathrm{a} \\
(0.118)\end{array}$ & & & \\
\hline \multirow[t]{3}{*}{2008} & May & $\begin{array}{l}2.30 \mathrm{~b} \\
(0.27)\end{array}$ & $\begin{array}{l}2.40 \mathrm{~b} \\
(1.14)\end{array}$ & $\begin{array}{l}8.01 \mathrm{a} \\
(3.09)\end{array}$ & $\begin{array}{l}3.7 \mathrm{~b} \\
(0.8)\end{array}$ & $\begin{array}{l}4.5 \mathrm{~b} \\
(1.6)\end{array}$ & $\begin{array}{l}11.7 \mathrm{a} \\
(2.0)\end{array}$ & $\begin{array}{l}0.108 \mathrm{~b} \\
(0.007)\end{array}$ & $\begin{array}{l}0.112 b \\
(0.052)\end{array}$ & $\begin{array}{l}0.333 \mathrm{a} \\
(0.118)\end{array}$ & & & \\
\hline & Jul & $\begin{array}{l}3.12 \mathrm{a} \\
(0.90)\end{array}$ & $\begin{array}{l}2.85 \mathrm{a} \\
(1.45)\end{array}$ & $\begin{array}{l}7.59 \mathrm{a} \\
(2.25)\end{array}$ & $\begin{array}{l}4.7 \mathrm{a} \\
(1.5)\end{array}$ & $\begin{array}{l}4.7 \mathrm{a} \\
(1.7)\end{array}$ & $\begin{array}{l}8.7 \mathrm{a} \\
(2.0)\end{array}$ & $\begin{array}{l}0.136 \mathrm{a} \\
(0.027)\end{array}$ & $\begin{array}{l}0.131 \mathrm{a} \\
(0.064)\end{array}$ & $\begin{array}{l}0.305 \mathrm{a} \\
(0.085)\end{array}$ & $\begin{array}{l}8.0 \mathrm{a} \\
(2.7)\end{array}$ & $\begin{array}{l}7.2 \mathrm{a} \\
(3.8)\end{array}$ & $\begin{array}{l}9.0 \mathrm{a} \\
(4.0)\end{array}$ \\
\hline & Sep & $\begin{array}{l}4.02 \mathrm{a} \\
(1.02)\end{array}$ & $\begin{array}{l}2.30 \mathrm{a} \\
(1.23)\end{array}$ & $\begin{array}{l}5.35 \mathrm{a} \\
(0.58)\end{array}$ & $\begin{array}{l}4.7 \mathrm{a} \\
(1.1)\end{array}$ & $\begin{array}{l}4.7 \mathrm{a} \\
(2.0)\end{array}$ & $\begin{array}{l}9.0 \mathrm{a} \\
(2.6)\end{array}$ & $\begin{array}{l}0.157 \mathrm{a} \\
(0.023)\end{array}$ & $\begin{array}{l}0.110 \mathrm{a} \\
(0.057)\end{array}$ & $\begin{array}{l}0.236 \mathrm{a} \\
(0.037)\end{array}$ & & & \\
\hline \multirow[t]{3}{*}{2010} & May & $\begin{array}{l}4.25 \mathrm{a} \\
(1.14)\end{array}$ & $\begin{array}{l}2.72 \mathrm{a} \\
(1.40)\end{array}$ & $\begin{array}{l}7.16 \mathrm{a} \\
(1.99)\end{array}$ & $\begin{array}{l}3.5 \mathrm{~b} \\
(0.9)\end{array}$ & $\begin{array}{l}5.2 \mathrm{ab} \\
(2.2)\end{array}$ & $\begin{array}{l}10.0 \mathrm{a} \\
(2.9)\end{array}$ & $\begin{array}{l}0.155 \mathrm{a} \\
(0.025)\end{array}$ & $\begin{array}{l}0.127 \mathrm{a} \\
(0.062)\end{array}$ & $\begin{array}{l}0.286 \mathrm{a} \\
(0.077)\end{array}$ & & & \\
\hline & Jul & $\begin{array}{l}6.04 \mathrm{a} \\
(1.81)\end{array}$ & $\begin{array}{l}4.47 \mathrm{a} \\
(2.31)\end{array}$ & $\begin{array}{l}9.85 \mathrm{a} \\
(2.31)\end{array}$ & $\begin{array}{l}5.2 \mathrm{a} \\
(1.6)\end{array}$ & $\begin{array}{l}6.5 \mathrm{a} \\
(2.5)\end{array}$ & $\begin{array}{l}11.0 \mathrm{a} \\
(2.5)\end{array}$ & $\begin{array}{l}0.195 \mathrm{a} \\
(0.031)\end{array}$ & $\begin{array}{l}0.192 \mathrm{a} \\
(0.095)\end{array}$ & $\begin{array}{l}0.377 \mathrm{a} \\
(0.089)\end{array}$ & $\begin{array}{l}8.5 \mathrm{a} \\
(3.1)\end{array}$ & $\begin{array}{l}8.2 \mathrm{a} \\
(4.6)\end{array}$ & $\begin{array}{l}11.7 \mathrm{a} \\
(4.7)\end{array}$ \\
\hline & Sep & $\begin{array}{l}4.81 \mathrm{a} \\
(1.25)\end{array}$ & $\begin{array}{l}3.89 \mathrm{a} \\
(2.11)\end{array}$ & $\begin{array}{l}5.60 \mathrm{a} \\
(2.83)\end{array}$ & $\begin{array}{l}5.0 \mathrm{a} \\
(1.5)\end{array}$ & $\begin{array}{l}6.0 \mathrm{a} \\
(2.0)\end{array}$ & $\begin{array}{l}7.3 \mathrm{a} \\
(1.7)\end{array}$ & $\begin{array}{l}0.189 \mathrm{a} \\
(0.035)\end{array}$ & $\begin{array}{l}0.167 \mathrm{a} \\
(0.081)\end{array}$ & $\begin{array}{l}0.225 \mathrm{a} \\
(0.099)\end{array}$ & & & \\
\hline
\end{tabular}

HWA plots to mean percent cover, richness and diversity in the REF plots were approximately 0.40 (Fig. 5a-c). By mid summer 2008, the mean ratios of cover and diversity increased to 0.60 in the GDL plots. Then, in the late summer 2010, all ratios were significantly higher with $0.82,0.71$, and 0.69 for cover, richness and diversity, respectively.

Ratio of mean tree seedling number in the GDL and HWA plots to mean tree seedling number in the REF plots was significantly different among years $\left(\mathrm{F}_{4,35}=4.98\right.$, $\mathrm{p}=0.0028$ ). The ratio of mean tree seedlings was nearly 0.0 in 2004, as there were only two tree seedlings recorded across all GDL and HWA plots (Fig. 5d). By mid summer 2006, more tree seedlings recruited into treated plots (Table 3), but the high variation resulted in no significant difference between 2004 and 2006. By mid summer 2008, ratio of tree seedlings was significantly higher than in $2004(\mathrm{t}=-2.77$, $\mathrm{p}=0.0051)$, when the mean ratio was more than 0.80 . No significant difference was found between 2008 and 2010 $(\mathrm{t}=0.59, \mathrm{p}=0.97)$.

Over the course of the study, we found that none of the tree seedlings in the ground layer recruited into the size class that was $>2.54 \mathrm{~cm}$. The only species that recruited into the size class $>2.54 \mathrm{~cm}$ was rhododendron (data not shown). The percent increase in rhododendron stems into this size class did not vary among treatments $\left(\mathrm{F}_{4,12}=1.87, \mathrm{p}=0.20\right)$ and averaged $6 \%( \pm 3 \%)$ from 2004 to 2010 .

\section{Discussion}

\section{Light and soil moisture}

Mortality of an overstory species that occupies over 50\% of the basal area would be expected to substantially impact micro-environmental conditions. We observed small, but statistically significant increases in light levels at 5 and $1 \mathrm{~m}$ above ground level (especially during leaf-off periods); the magnitude of the response was dampened by two factors. First, hemlock trees killed by both the GDL and HWA treatments remained standing and retained most of their branch area. Hence, in contrast to larger gaps that might occur with tree mortality that is coincident with tree-fall or branch breakage and removal (i.e. hurricanes or tornados, Beckage et al. 2000), the early stages of hemlock mortality (at least at this point) were primarily associated with needle loss (Nuckolls et al. 2009). Greater changes in light levels may occur in coming years as these dead trees begin to shed branches or fall. Second, dense evergreen shrubs had the effect of neutralizing the potential increase in light levels reaching $1 \mathrm{~m}$ above ground height. In the southern Appalachians, it is not uncommon for rhododendron density to exceed 5000 stems $\mathrm{ha}^{-1}$ (Clinton et al. 1994) and as high as 17000 stems ha ${ }^{-1}$ (Baker and van Lear 1998); hence, it exerts a profound influence on incident light beneath its canopy. This is in stark 
Table 3. Ground layer vegetation species presence across all plots for the three treatments; girdled (GDL), HWA-infested (HWA), and neighboring hardwoods (REF). For tree seedlings, the number in parentheses is the total number of seedlings observed across all transects in the treatment plots for that year. ${ }^{1}$ species only observed in the May sample; ${ }^{2}$ species only observed in the September sample, otherwise species were observed in all sample months of that year. Species nomenclature follows Gleason and Cronquist (1991).

\begin{tabular}{lllrrr}
\hline 2004 & 2006 & 2007 & 2008 & 2010 \\
\hline GDL & & Tree seedlings
\end{tabular}

\section{GDL}

Tree seedlings

$\begin{array}{llll}\text { Acer rubrum (13) } & \text { A. rubrum (8) } & \text { A. rubrum (5) } & \text { A. rubrum (21) } \\ \text { Liriodendron tulipifera (1) } & \text { Amelanchier arborea (1) } & \text { A. arborea (22) } & \text { Betula lenta (5) } \\ \text { Oxydendrum arboreum (6) } & \text { O. arboreum (6) } & \text { L. tulipifera (1) } & \text { L. tulipifera (1) } \\ \text { Quercus rubra (3) } & \text { Q. rubra (3) } & \text { Magnolia fraseri (1) } & \text { O. arboreum (4) } \\ & & \text { O. arboreum (2) } & \text { Q. coccinea (1) } \\ & & \text { Quercus rubra (1) } & \text { Q. rubra (2) }\end{array}$

Chimaphila maculata

Galax aphylla

Rhododendron maximum

Smilax rotundifolia

HWA

Acer rubrum (1)

Tsuga canadensis (1)

Chimaphila maculata

Galax aphylla

Gaylussacia ursina

Goodyera pubescens

Mitchella repens

Rhododendron maximum

Smilax rotundifolia

Thelypteris noveboracencis

$\begin{array}{ll}\text { Erythronium americanum }{ }^{1} & \text { E. americanum } \\ \text { G. aphylla } & \text { G. aphylla } \\ \text { R. maximum } & \text { R. maximum } \\ \text { Smilax glauca } & \text { S. glauca } \\ \text { S. rotundifolia } & \text { S. rotundifolia }\end{array}$

tree seedlings

A. rubrum (8)

Amelanchier arborea (7)

Liriodendron tulipifera (1)

Nyssa sylvatica (3)

herbs, shrubs and vines

Carex sp.
E. americanum ${ }^{1}$
G. aphylla
R. maximum
S. glauca
S. rotundifolia

$$
\begin{aligned}
& \text { Carex sp. } \\
& \text { E. americanum } 1 \\
& \text { G. aphylla } \\
& \text { Parthenocissus } \\
& \quad \text { quinquefolia } \\
& \text { R. maximum } \\
& \text { S. glauca } \\
& \text { S. rotundifolia }
\end{aligned}
$$

A. rubrum (11)

A. arborea (1)

Betula lenta (17)

Fraxinus americana (2)

L. tulipifera (1)

Q. velutina (1)

$\begin{array}{ll}\text { C. maculata } & \text { C. maculata } \\ \text { G. aphylla } & \text { G. aphylla } \\ \text { G. ursina } & \text { G. ursina } \\ \text { G. pubescens } & \text { G. pubescens } \\ \text { M. repens } & \text { M. repens } \\ \text { Polystichum acrostichoides } & \text { P. acrostichoides } \\ \text { R. maximum } & \text { R. maximum } \\ \text { S. glauca } & \text { S. glauca } \\ \text { S. rotundifolia } & \text { S. rotundifolia } \\ \text { T. noveboracencis } & \text { Viola hastata }\end{array}$

tree seedlings
A. rubrum (8)

A. arborea (1)

C. caroliniana (3)

C. glabra (14)

C. dentata (4)

Cornus florida (1)

M. fraseri (1)

N. sylvatica (2)

P. serotina (1)

Q. alba (8)

Q. coccinea (5)

Q. velutina (2)

S. albidum (1)

herbs, shrubs and vines

Chimaphila maculata Desmodium nudiflorum Euonymus americanus Galium latifolium Gaylussacia ursina Mitchella repens

Athyrium filix-femina
Carex sp.
C. maculata
D. nudiflorum
E. americanus
G. aphylla
Carex sp.
C. maculata
D. nudiflorum
E. americanus
G. latifolium
G. ursina

C. maculata
G. aphylla
G. ursina
G. pubescens
M. repens
P. acrostichoides
R. maximum
S. glauca
S. rotundifolia
T. noveboracencis
V. hastata1

G. aphylla

G. ursina

G. pubescens

M. repens

P. acrostichoides

R. maximum

S. rotundifolia

T. noveboracencis

Trillium sp. ${ }^{1}$

V. hastata
A. rubrum (11)
A. arborea (1)
C. glabra (6)
C. tomentosa (3)
C. pumila (3)
F. americana (1)
M. fraseri (2)
Q. alba (5)
Q. coccinea (2)
Q. velutina (1)
A. filix-femina
Carex sp.
C. maculata
D. nudiflorum
E. americanus
G. latifolium
A. filix-femina
C. maculata
D. nudiflorum
E. americanus
G. latifolium
G. ursina 


\begin{tabular}{lllll}
\hline \multicolumn{1}{c}{2004} & \multicolumn{1}{c}{2006} & \multicolumn{1}{c}{2007} & 2008 & \multicolumn{1}{c}{2010} \\
\hline Poa sp. & G. latifolium & M. lineare & G. ursina & M. lineare \\
Rhododendron maximum & G. ursina & M. repens & M. lineare & R. maximum \\
Smilax glauca & Melampyrum lineare & P. quinquefolia & M. repens & S. glauca \\
Smilax rotundifolia & M. repens & P. acrostichoides & R. maximum & S. rotundifolia \\
Thelypteris noveboracencis & R. maximum & R. maximum & S. glauca & T. noveboracencis \\
Toxicodendron radicans & S. glauca & S. glauca & S. rotundifolia & Trillium sp. ${ }^{1}$ \\
Viola sp. & S. rotundifolia & S. rotundifolia & T. noveboracencis & Viola sp. \\
& T. noveboracencis & Stellaria pubera ${ }^{2}$ & Trillium sp. ${ }^{2}$ & \\
& Viola sp. & T. noveboracencis & Viola sp. & \\
& & Trillium sp. ${ }^{1}$ & & \\
& & Viola sp. & & \\
& & &
\end{tabular}

contrast to the changes in light in declining hemlock stands in the northeast, which lack a dense shrub canopy. For example, Orwig and Foster (1998) showed that in New England hemlock forests, light incident onto the ground layer vegetation could be 2-4 times greater in infested and declining stands compared to healthier stands.

Our previous work estimated that hemlock mortality would reduce watershed-scale transpiration by as much as $10 \%$ annually (Ford and Vose 2007). Thus we expected an increase in soil moisture over time in both the GDL and the HWA plots. However, we did not detect a statistically significant change in either response. This may be due to a combination of factors, such as high within treatment variability, variable climate over the study period, and topographic effects. For example, because plots were located in wide and flat riparian areas near perennial third order streams, soil moisture was almost always $>20 \%$ (ranging up to $45 \%$ ) and perhaps less impacted by vegetation water use than drainage. In addition, it is likely that water use by both trees and shrubs increased in response to hemlock mortality, offsetting the decrease in hemlock transpiration and thus dampening the soil moisture response.

\section{Mortality and growth of canopy and shrub species}

Eastern hemlock mortality is occurring rapidly in the southern Appalachians. Our model predicts $100 \%$ mortality by 2012. Surprisingly few studies have reported rates of HWAmediated hemlock mortality, especially in the southern range of the infestation. However, mortality rate following initial infestation appears to be variable across regions and within a geographical region depending on other factors, including site characteristics, climatic influence, genetic factors, rate of HWA dispersal, or success of bio-control agents. For a hemlock-dominated forest in New York, Lewis et al. (2008) reported greater than $50 \%$ hemlock tree mortality during their study period (1985-2002). Although they did not report the time of the first observation of HWA infestation, if we assume that their study began at the early stages HWA infestation, 50\% mortality in 17 years is considerably slower than the $50 \%$ in 7 years observed in our study. For sites in Pennsylvania and New Jersey, Eschtruth et al. (2006) reported that only $15 \%$ of hemlock trees had experienced mortality after 9 years of HWA infestation (1994-2003). In another study in southeastern Connecticut, $45 \%$ hemlock mortality was observed 10 years after initial infestation, and $80 \%$ mortality was observed after 15 years (Small et al. 2005). In contrast, our southern Appalachian study sites have reached $80 \%$ mortality after 6 years of infestation.

Multiple factors affect tree health decline and mortality rates (Manion 1981, Waring 1987). High eastern hemlock mortality rates in our study were likely a product of several climatic and biological effects. Most important among these is the interaction among HWA population density, temperature and soil moisture. HWA populations can remain high if winter air temperature is relatively high (Skinner et al. 2003, Trotter and Shields 2009). The absolute minimum winter air temperature recorded during our study was $-15.6^{\circ} \mathrm{C}$, considerably warmer than the $-30^{\circ} \mathrm{C}$ lethal HWA population temperature (Parker et al. 1998, 1999), and warmer than the -16 to $-21^{\circ} \mathrm{C}$ range of super-cooling points for southern Appalachian HWA populations (Costa et al. 2008). Although HWA population density is negatively affected by temperatures below freezing (Parker et al. 1999), it is likely that densities remained high enough to facilitate rapid host mortality. Trees are particularly vulnerable to mortality when predisposed to stress (e.g. from persistent HWA infestation), and if other stressors are encountered, the combination of stressors can incite mortality (Manion 1981). For example, during our study a severe drought was pervasive across most of the eastern US. In the 75-year record of precipitation at our study location, the driest year on record occurred in 2007 with $1212 \mathrm{~mm}$, a deficit of more than $30 \%$ of the long-term average (Laseter et al. in press). This drought may have contributed to the rapid mortality observed, as drought plays an important role in tree mortality (Allen et al. 2010). Interestingly, the last major decline in eastern hemlock occurring 5500 years ago was associated with both widespread drought and insect outbreak (Allison et al. 1986, Foster et al. 2006).

As hemlock rapidly declined in these stands, the co-occurring trees and shrubs responded with increases in growth; but the growth responses of trees and shrubs were out of phase, and different in magnitude. Initially, growth of hardwoods co-occurring with HWA infested or girdled hemlock trees was ca $80 \%$ of that of hardwoods growing in reference stands with little hemlock presence. By the end of the study, their growth increased 1.1-1.2 times over of that of hardwoods growing in reference stands. The greatest increase in growth occurred in the first two years (25-30\%), with smaller incremental increases thereafter (ca 10\%). The high initial growth rate is likely in response to a rapid increase 


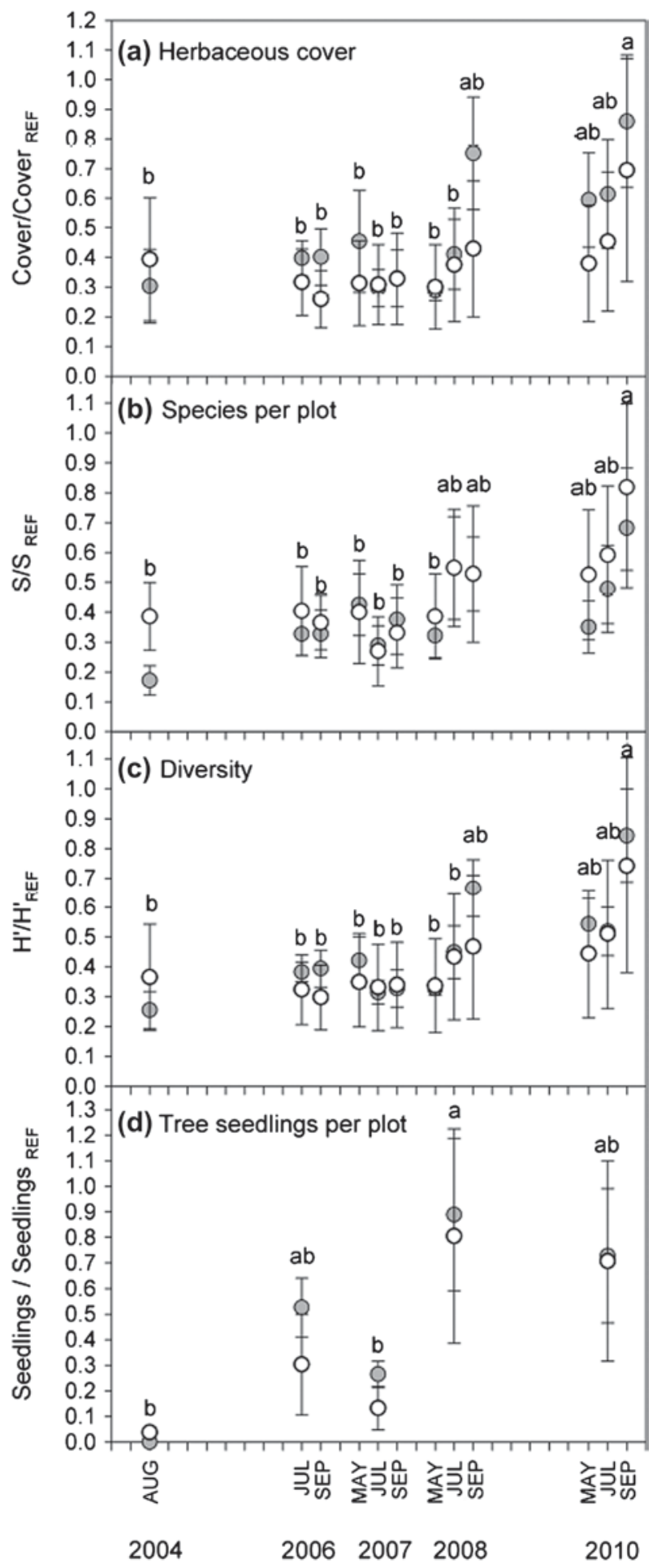

Figure 5. Ground layer (a) mean cover, (b) species richness (S, number of species per plot, (c) diversity ( $\mathrm{H}^{\prime}$, Shannon's index), and (d) tree seedlings per plot in girdled (GDL, grey symbols) and HWA-infested (HWA, white symbols) treatments relative to the mean in the neighboring hardwood plots (REF, $<3 \%$ hemlock basal area). Ground layer vegetation includes woody stems $<0.5 \mathrm{~m}$ height and all herbaceous plants. Bars denote standard error. Different letters denote statistically significant differences among sample dates. No treatment or treatment by time interaction effects were detected $(\alpha=0.05)$. Girdling occurred in July 2004. HWA infestation was observed in December 2004. in upper and mid-canopy light availability in both girdled and infested stands; however, light availability (and hence, growth response) would be expected to decline as canopy gaps are filled-in by responding species. Interestingly, growth response patterns in the GDL and HWA treatments were comparable, despite the fact the former had 100\% hemlock mortality and the latter had 50\%. Although we did not quantify crown condition on these plots, leaf litter fall on these plots had similar cumulative amounts over 2004-2006 (Nuckolls et al. 2009). This rapid rate of leaf loss is common for infested hemlock trees in the southern Appalachians, as a related extensive study in the Coweeta basin showed that over $80 \%$ of the crowns of the HWA infested tress (but still living) were lost within 5 years (Elliott and Vose 2011). As such, the growth response of residual trees was comparable for both the rapid (GDL) and slow mortality (HWA) treatments.

In contrast to the response patterns of the canopy species, growth of evergreen shrubs in the infested and girdled plots had similar growth rates compared to those in reference stands during the initial years of the study. By the end of the study, however, their growth increased 2.6 times higher than the shrubs growing in reference stands. The greatest increase in growth occurred between the third and fourth years (ca 1.1 fold), and continued to increase thereafter. The continuing growth response in evergreen species may reflect the impact of a near two-fold increase in light incident on $5 \mathrm{~m}$ above ground height, especially during the winter and spring, but also to a lesser extent in the summer and fall. Because of its evergreen leaf habit, rhododendron can capitalize on increased light availability in early spring when conditions are suitable for carbon fixation (Russell et al. 2009), but prior to leaf out of deciduous species. Thus, higher incident light in the spring likely contributed significantly to the high growth response of rhododendron.

The increase in basal area of evergreen shrubs will also influence evapotranspiration and carbon gain. Most of this shrub basal area was comprised of rhododendron, which increased $17 \%$ over the study period. We estimate that sapwood area of this species increased by $214 \mathrm{~cm}^{2}$ per plot during 2004-2009, which was more than twice the increase in sapwood area of this species in the reference stands (allometric equation for $\mathrm{SWA}=12.134 \times \exp (\mathrm{DBH} \times 0.17$ 2), $\mathrm{R}^{2}=0.97, \mathrm{n}=10$, C. Ford unpubl.). The corresponding increase in projected leaf area (LA) was $43 \mathrm{~m}^{2}$ per plot, which was 1.6 times higher than the increase in leaf area of this species in the reference stands (allometric equation for $\mathrm{LA}=1.29 \times \mathrm{DBH}-0.863, \mathrm{R}^{2}=0.73, \mathrm{n}=8$, B. Kloeppel unpubl.). Rhododendron carbon gain is highly seasonal, with peaks occurring in spring and fall during the leaf-off time of canopy deciduous trees when light transmittance into the subcanopy is high (Russell et al. 2009). From reported average spring net carbon gain for this species $\left(2 \mu \mathrm{mol} \mathrm{m} \mathrm{m}^{-2}\right.$ $s^{-1}$ (Russell et al. 2009)), we estimate that by 2009, average spring carbon gain by rhododendron was $\sim 25 \mu \mathrm{mol} \mathrm{C} \mathrm{s}{ }^{-1}$ greater in the infested and girdled stands compared to that in the reference stands. This represents a conservative estimate, as it does not take into consideration the changes in incident light, only the change in leaf area. Actual changes in carbon gain are likely to be greater and are a focus of our ongoing research. 


\section{Ground layer vegetation recruitment}

In 2004 , the heavy shade provided by healthy hemlock prohibited the recruitment of many herbaceous and tree seedling species. Although light penetration $1 \mathrm{~m}$ above ground height remained low after 2004 in infested and girdled stands due to the presence of rhododendron, the increasing transmittance over time coupled with relatively high soil moisture in the spring seasons may have contributed to the small, but significant increases in tree seedling densities (Ibáńez et al. 2007). Rhododendron inhibits growth and germination of other species by also reducing soil resources (Wurzburger and Hendrick 2007, 2009). Since rhododendron occurs in dense thickets in hemlock and hardwood riparian forests alike in the southern Appalachians (Kincaid and Parker 2008), its presence will dampen the otherwise unique influence of hemlock mortality on riparian environmental conditions. In our study, rhododendron was abundant in all girdled, infested and hardwood reference plots; however, it did not have $100 \%$ coverage. The interspaces between rhododendron patches allowed recruitment and growth of herbs and tree seedlings into canopy gaps created by hemlock mortality. Despite the positive response by the ground layer vegetation, the presence of rhododendron muted the magnitude of the response compared to declining hemlock forests without rhododendron, i.e. northeast HWA infested hemlock forests. For example, in New England, Eschtruth et al. (2006) found that vascular plant coverage increased from 3.1 to $11.3 \%$ over nine years with gradual thinning of the hemlock canopy by HWA infestation. Yorks et al. (2003) found that understory cover more than doubled in the first three years after girdling hemlock stands to simulate rapid infestation. In contrast, in our study ground layer vegetation coverage only increased from 3.8 to $5.2 \%$ (averaged across all treatment plots) over seven years. Our responses in infested and girdled plots are converging towards cover, richness and diversity levels found in hardwood/rhododendron forests, but they do not approach levels recorded in hardwood forests without rhododendron (Elliott et al. 2011). For example, in the southern Appalachians, mature hardwood forests without a rhododendron subcanopy often have 100\% cover of ground layer vegetation and more than 30 species per 0.08 ha (Elliott and Knoepp 2005).

Studies in the northeastern US have projected that in the short-term black birch will be the dominant species to replace hemlock following HWA-induced hemlock mortality, as it shows prolific growth following HWA infestation and hemlock mortality in many studies (Orwig and Foster 1998, Kizlinski et al. 2002, Orwig et al. 2002, Stadler et al. 2005, Sullivan and Ellison 2006). We also found increases in black birch seedling establishment; however, this species did not dominate the response. We found a mix of hardwood species recruiting into the ground layer as hemlock mortality increased over time. Our results were similar to those in the central and southern Appalachians that suggest a mix of Acer, Betula, Fagus and Quercus canopy genera, if they can become established, will most likely replace declining hemlock (Kincaid 2007, Heard and Valente 2009, Spaulding and Rieske 2010). However, the small response of the ground layer and the large response of the shrubs may likely portend the longterm changes in community composition of these forests.
Evergreen shrubs, once established, can persist for many decades; for example, Plocher and Carvel (1987) described rhododendron thickets that ranged 57-122 years old, and Johnson and Kovner (1956) described rhododendron aging 85-100 years old (established in the mid 1800s). And, in the recent past, prolific rhododendron establishment was associated with cessations of widespread disturbances that left the canopy open (e.g. logging, Johnson and Kovner 1956, fire and grazing, McGee and Smith 1967). As large woody debris falls from the canopy of infested hemlock stands, resulting large canopy gaps will likely facilitate tree seedling recruitment and shrub growth.

\section{Conclusions}

The impacts of hemlock woolly adelgid on the structure and function of southern Appalachian ecosystems will take decades to fully quantify and understand. In the short-term, the results of our study suggest different impacts of infestation on canopy and shrub species, and ground layer vegetation, with the latter being substantially influenced by the presence of rhododendron shrubs. Growth response of overstory trees occurred in the first few years following hemlock decline and mortality. Although $50 \%$ of the hemlock trees were still considered 'alive' five years after infestation based on the presence of live green foliage in the crowns, the amount of leaf area lost was considerable. As such, overall responses (microenvironment, growth, understory, etc.) in the HWA stands were identical to the girdled stands with $100 \%$ mortality. In contrast, rhododendron has continued to increase its growth response, most likely taking advantage of the increased light available during leaf-off periods of the deciduous species. Increased growth and dominance of rhododendron will be a major determinant of future responses in southern Appalachian ecosystems; however, our results suggest a mix of Acer, Betula, Fagus and Quercus canopy genera where establishment is not as limited by the direct and indirect effects of rhododendron.

Finally, the majority of studies quantifying the effects of invasive insects focus on ecological effects rather than the effects on ecosystems processes or services (Kenis et al. 2009). However, quantifying the latter is key information for restoration efforts and land use management options following invasions that extirpate a foundation species such as eastern hemlock (Ellison et al. 2005). Similar response patterns between girdled and infested stands attest to the 'virulence' of HWA in the southern Appalachians (Lovett et al. 2006). As such, the rapid (and likely irreversible due to the expansion of rhododendron) impacts of HWA mortality on ecosystem processes may be even greater than that reported for New England forests (Catovsky et al. 2002, Hadley 2002).

Acknowledgements - This study was supported by the USDA Forest Service, Southern Research Station and by NSF grant DEB0218001 to the Coweeta LTER program at the Univ. of Georgia. Any opinions, findings, conclusions, or recommendations expressed in the material are those of the authors and do not necessarily reflect the views of the National Science Foundation or the Univ. of Georgia. We are grateful to S. Brantley, R. Cobb, K. Martin and $\mathrm{N}$. Pederson for providing helpful comments on a previous version of this manuscript. We acknowledge the support of many 
individuals, past and present, as well as the long-term climate and hydrologic data network at Coweeta Hydrologic Lab, especially K. Bower, P. Clinton, J. P. Love, R. McCollum, N. Muldoon, A. Martin, J. Meador, S. Skolochenko, G. Taylor, and G. Zausen for field work and climate data collection and processing.

\section{References}

Allen, C. D. et al. 2010. A global overview of drought and heat-induced tree mortality reveals emerging climate change risks for forests. - For. Ecol. Manage. 259: 660-684.

Allison, T. D. et al. 1986. Pollen in laminated sediments provides evidence of mid-Holocene forest pathogen outbreak. - Ecology 67: 1101-1105.

Austin, A. T. and Vivanco, L. 2006. Plant litter decomposition in a semi-arid ecosystem controlled by photodegradation. - Nature 442: 555-558.

Baker, T. T. and van Lear, D. H. 1998. Relations between density of rhododendron thickets and diversity of riparian forests. - For. Ecol. Manage. 109: 21-32.

Beckage, B. et al. 2000. A long-term study of tree seedling recruitment in southern Appalachian forests: the effects of canopy gaps and shrub understories. - Can. J. For. Res. 30: 1617-1631.

Catovsky, S. et al. 2002. Coupling whole-tree transpiration and canopy photosynthesis in coniferous and broad-leaved tree species. - Can. J. For. Res. 32: 295-309.

Cattelino, P. J. et al. 1986. Construction and installation of homemade dendrometer bands. - North. J. Appl. For. 3: 73-75.

Clarke, R. 1986. The handbook of ecological monitoring. - Clarendon Press.

Clinton, B. D. 2003. Light, temperature, and soil moisture responses to elevation, evergreen understory, and small canopy gaps in the southern Appalachians. - For. Ecol. Manage. 186: 243-255.

Clinton, B. D. et al. 1994. Regeneration patterns in canopy gaps of mixed-oak forests of the southern Appalachians: influences of topographic position and evergreen understory. - Am. Midl. Nat. 132: 308-319.

Cobb, R. C. 2010. Species shift drives decomposition rates following invasion by hemlock woolly adelgid. - Oikos 119: 1291-1298.

Costa, S. D. et al. 2008. Low temperature in the hemlock woolly adelgid system. - In: Onken, B. and Reardon, R. (eds), 4th Symp. on Hemlock Woolly Adelgid in the eastern US. USDA For. Service, FHTET-2008-01, pp. 47-52.

Crowl, T. A. et al. 2008. The spread of invasive species and infectious disease as drivers of ecosystem change. - Front. Ecol. Environ. 6: 238-246.

Daehler, C. C. 2003. Performance comparisons of co-occurring native and alien invasive plants: Implications for conservation and restoration. - Annu. Rev. Ecol. Evol. Syst. 34: 183-211.

Daley, M. J. et al. 2007. Water use by eastern hemlock (Tsuga canadensis) and black birch (Betula lenta): implications of effects of the hemlock woolly adelgid. - Can. J. For. Res. 37: 2031-2040.

Elliott, K. J. and Knoepp, J. D. 2005. The effects of three regeneration harvest methods on plant diversity and soil characteristics in the southern Appalachians. - For. Ecol. Manage. 211: 296-317

Elliott, K. J. and Swank, W. T. 2008. Long-term changes in forest composition and diversity following early logging (1919-1923) and the decline of American chestnut (Castanea dentata). - Plant Ecol. 197: 155-172.

Elliott, K. J. and Vose, J. M. 2011. The contribution of the Coweeta Hydrologic Laboratory to developing an understanding of long-term (1934-2008) changes in managed and unmanaged forests. - For. Ecol. Manage. 261: 900-910.

Elliott, K. J. et al. 1999. Long-term patterns in vegetation-site relationships in a southern Appalachian forest. - J. Torrey Bot. Soc. 126: 320-334.
Elliott, K. J. et al. 2011. Herbaceous response to type and severity of disturbance. - In: Greenberg, C. H. et al. (eds), Sustaining young forest communities. Springer seriesa: Managing Forest Ecosystems, Vol. 21, chapter 7. Springer, pp. 97-119.

Ellison, A. M. et al. 2005. Loss of foundation species: consequences for the structure and dynamics of forested ecosystems. - Front. Ecol. Environ. 9: 479-486.

Enserink, M. 1999. Biological invaders sweep in. - Science 285: 1834-1836.

Eschtruth, A. K. et al. 2006. Vegetation dynamics in declining eastern hemlock stands: nine years of forest response to hemlock woolly adelgid infestation. - Can. J. For. Res. 36: 1435-1450.

Flory, S. L. and Clay, S. 2010. Non-native grass invasion suppresses forest succession. - Oecologia 164: 1029-1038.

Ford, C. R. and Vose, J. M. 2007. Tsuga canadensis (L.) Carr. mortality will impact hydrologic processes in southern Appalachian forest ecosystems. - Ecol. Appl. 17: 1156-1167.

Foster, D. R. and Zebryk, T. M. 1993. Long-term vegetation dynamics and disturbance history of a Tsuga-dominated forest in New England. - Ecology 74: 982-998.

Foster, D. R. et al. 2006. A climatic driver for abrupt mid-Holocene vegetation dynamics and the hemlock decline in New England. - Ecology 87: 2959-2966.

Fritts, H. C. 1976. Tree rings and climate. - Academic Press.

Gleason, H. A. and Cronquist, A. 1991. Manual of vascular plants of northeastern United States and adjacent Canada. - N. Y. Bot. Gard.

Gordon, D. R. 1998. Effects of invasive, non-indigenous plant species on ecosystem processes: lessons from Florida. - Ecol. Appl. 8: 975-989.

Hadley, J. L. 2002. Carbon exchange of an old-growth eastern hemlock (Tsuga canadensis) forest in central New England. - Tree Physiol. 22: 1079-1092.

Heard, M. J. and Valente, M. J. 2009. Fossil pollen records forecast response of forests to hemlock woolly adelgid invasion. - Ecography 32: 881-887.

Hille Ris Lambers, J. and Clark, J. S. 2003. Effects of dispersal, shrubs, and density-dependent mortality on seed and seedling distributions in temperate forests. - Can. J. For. Res. 33: 783-795.

Hulme, P. E. 2009. Trade, transport and trouble: managing invasive species pathways in an era of globalization. - J. Appl. Ecol. 46: 10-18.

Ibánez, I. et al. 2007. Exploiting temporal variability to understand tree recruitment response to climate change. - Ecol. Monogr. 77: 163-177.

Johnson, E. A. and Kovner, J. L. 1956. Effect on streamflow of cutting a forest understory. - For. Sci. 2: 82-91.

Kenis, M. et al. 2009. Ecological effects of invasive alien insects. - Biol. Invas. 11: 21-45.

Kincaid, J. A. 2007. Compositional and environmental characteristics of Tsuga Canadensis (L.) Carr. forests in the southern Appalachian Mountains, USA. - J. Torrey Bot. Soc. 134: 479-488.

Kincaid, J. and Parker, A. 2008. Structural characteristics and canopy dynamics of Tsuga canadensis in forests of the southern Appalachian Mountains, USA. - Plant Ecol. 199: 265-280.

Kizlinski, M. L. et al. 2002. Direct and indirect ecosystem consequences of an invasive pest on forests dominated by eastern hemlock. - J. Biogeogr. 29: 1489-1503.

Knapp, A. K. et al. 2008. Shrub encroachment in North American grasslands: shifts in growth form dominance rapidly alters control of ecosystem carbon inputs. - Global Change Biol. 14: 615-623.

Laseter, S. H. et al. Long-term temperature and precipitation trends at the Coweeta Hydrologic Laboratory, Otto, North Carolina, USA. - Hydrol. Res., in press. 
Lett, M. S. and Knapp, A. K. 2003. Consequences of shrub expansion in mesic grassland: resource alterations and graminoid responses. - J. Veg. Sci. 14: 487-496.

Lewis, J. D. et al. 2008. Oak seedling growth and ectomycorrhizal colonization are less in eastern hemlock stands infested with hemlock woolly adelgid than in adjacent oak stands. - Tree Physiol. 28: 629-636.

Little, R. C. et al. 1996. SAS system for mixed models. - SAS Inst.

Lovett, G. M. et al. 2006. Forest ecosystem responses to exotic pests and pathogens in eastern North America. - Bioscience 56: 395-405.

Lovett, G. M. et al. 2010. Long-term changes in forest carbon and nitrogen cycling caused by an introduced pest/pathogen complex. - Ecosystems 13: 1188-1200.

Magurran, A. E. 2004. Measuring biological diversity. - Blackwell.

Manion, P. D. 1981. Tree disease concepts. - Prentice-Hall.

McClure, M. S. 1989. Evidence of a polymorphic life cycle in the hemlock woolly adelgid, Adelges tsugae (Homoptera: Adelgidae). - Ann. Entomol. Soc. Am. 82: 50-54.

McGee, C. E. and Smith, R. C. 1967. Undisturbed rhododendron thickets are not spreading. - J. For. 65: 334-336.

Narayanaraj, G. et al. 2009. Terrain and landform influence on Tsuga canadensis (L.) Carriere (eastern hemlock) distribution in the southern Appalachian Mountains. - Castanea 75: 1-18.

Norris, M. D. et al. 2001. Land cover change in eastern Kansas: litter dynamics of closed-canopy eastern redcedar forests in tallgrass prairie. - Can. J. Bot. 79: 214-222.

Nuckolls, A. et al. 2009. Hemlock declines rapidly with hemlock woolly adelgid infestation: impacts on the carbon cycle of southern Appalachian forests. - Ecosystems 12: 179-190.

Orwig, D. A. and Foster, D. R. 1998. Forest response to the introduced hemlock woolly adelgid in southern New England, USA. - J. Torrey Bot. Soc. 125: 60-73.

Orwig, D. A. et al. 2002. Landscape patterns of hemlock decline in New England due to the introduced hemlock woolly adelgid. - J. Biogeogr. 29: 1475-1487.

Padilla, D. K. and Williams, S. L. 2004. Beyond ballast water: aquarium and ornamental trades as sources of invasive species in aquatic ecosystems. - Front. Ecol. Environ. 2: 131-138.

Parker, B. L. et al. 1998. Survival of hemlock woolly adelgid (Homoptera : Adelgidae) at low temperatures. - For. Sci. 44: 414-420.

Parker, B. L. et al. 1999. Low lethal temperature for hemlock woolly adelgid (Homoptera : Adelgidae). - Environ. Entomol. 28: 1085-1091.

Plocher, A. E. and Carvel, K. L. 1987. Population dynamics of rosebay rhododendron thickets in the southern Appalachians. - Bull. Torrey Bot. Club 114: 121-126.
Roberts, S. W. et al. 2009. Assessing the potential impacts to riparian ecosystems resulting from hemlock mortality in Great Smoky Mountains National Park. - Environ. Manage. 44: 335-345.

Russell, R. B. et al. 2009. Freezing induced leaf movements and their potential implications to early spring carbon gain: Rhododendron maximum as exemplar. - Funct. Ecol. 23: 463-471.

Skinner, M. et al. 2003. Regional responses of hemlock woolly adelgid (Homoptera : Adelgidae) to low temperatures. - Environ. Entomol. 32: 523-528.

Small, M. J. et al. 2005. Changes in a hemlock-dominated forest following woolly adelgid infestation in southern New England. - J. Torrey Bot. Soc. 132: 458-470.

Spaulding, H. and Rieske, L. 2010. The aftermath of an invasion: structure and composition of central Appalachian hemlock forests following establishment of the hemlock woolly adelgid, Adelges tsugae. - Biol. Invas. 12: 3135-3143.

Stadler, B. et al. 2005. Hemlock woolly adelgid in New England forests: canopy impacts transforming ecosystem processes and landscapes. - Ecosystems 8: 233-247.

Stadler, B. et al. 2006. The ecology of energy and nutrient fluxes in hemlock forests invaded by hemlock woolly adelgid. - Ecology 87: 1792-1804.

Sullivan, K. A. and Ellison, A. M. 2006. The seed bank of hemlock forests: implications for forest regeneration following hemlock decline. - J. Torrey Bot. Soc. 133: 393-402.

Swift, L. W. et al. 1988. Climate and hydrology. - In: Swank, W. T. and Crossley, D. A. (eds), Ecological studies, Vol. 66: forest hydrology and ecology at Coweeta. Springer, pp. 35-55.

Trotter, R. T. and Shields, K. S. 2009. Variation in winter survival of the invasive hemlock woolly adelgid (Hemiptera: Adelgidae) across the eastern United States. - Environ. Entomol. 38: 577-587.

Waring, R. H. 1987. Characteristics of trees predisposed to die. - Bioscience 37: 569-574.

Whigham, D. F. 2004. Ecology of woodland herbs in temperate deciduous forests. - Annu. Rev. Ecol. Evol. Syst. 35: 583-621.

Wurzburger, N. and Hendrick, R. L. 2007. Rhododendron thickets alter $\mathrm{N}$ cycling and soil extracellular enzyme activities in southern Appalachian hardwood forests. - Pedobiologia 50: $563-576$.

Wurzburger, N. and Hendrick, R. 2009. Plant litter chemistry and mycorrhizal roots promote a nitrogen feedback in a temperate forest. - J. Ecol. 97: 528-536.

Yorks, T. E. et al. 2003. Effects of Tsuga canadensis mortality on soil water chemistry and understory vegetation: possible consequences of an invasive insect herbivore. - Can. J. For. Res. 33: $1525-1537$. 